TAPROBANICA, ISSN 1800-427X. April, 2011. Vol. 03, No. 01: pp. 15-17, 2 pls.

(C) Taprobanica Private Limited, Jl. Kuricang 18 Gd.9 No.47, Ciputat 15412, Tangerang, Indonesia.

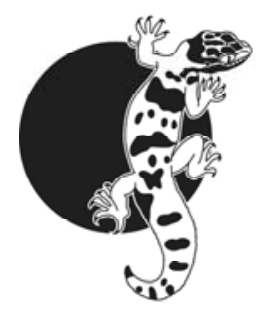

\title{
FOUR NEW ASTERINACEOUS MEMBERS FROM KERALA, INDIA
}

${ }^{1}$ Tropical Botanic Garden \& Research Institute, Palode - 695 562, Thiruvananthapuram, Kerala, India

* E-mail: vbhosagoudar@rediffmail.com

${ }^{2}$ Plant Pathology Division, Indian Agricultural Research Institute, New Delhi 110 012, India

\begin{abstract}
This paper gives an account of four new members belonging to the genera Asterina and Cirsosia, namely, Asterina aristolochiae, Asterina phyllanthi-beddomei, Cirsosia hopeae and Asterina thunbergiicola Hansford var. indica are described and illustrated.
\end{abstract}

Key words: black mildews, Asterina, Cirsosia, Kerala, India

\section{Introduction}

Peppara and Neyyar is twin and adjacent wildlife sanctuaries located on the western slope and in the penultimate end of the Western Ghats including the Agastyar peak in Thiruvananthapuram District of Kerala state, include the hotspot area of Agastyamala. These sanctuaries lie between $8^{\circ} 7^{\prime}$ $8^{\circ} 53^{\prime} \mathrm{N}$ and $70^{\circ} 4^{\prime}-77^{\circ} 17^{\prime} \mathrm{E}$, surrounded by Kalakkad and Mundandurai wildlife sanctuaries in the East, Palode and Paruthipalli forest range in the North. Both sanctuaries together have an area of $181 \mathrm{~km}^{2}$, with an altitudinal range from 100-1864 m a.s.l., temperature from $16-35{ }^{\circ} \mathrm{C}$, annual rain fall about $2800 \mathrm{~mm}$. Agastiar peak (1864 m), Pongalapara $(1500 \mathrm{~m})$ and Chemunji $(1000 \mathrm{~m})$ are the continuous hill ranges, located towards the Eastern side of the study area and steeply descend towards western side. Because of the varied topography, this area is rich in its plant diversity. We have been studying the foliicolous fungi of this region since 1996 and the present paper is the novelties of this study.

\section{Taxonomy}

1. Asterina aristolochiae sp. nov. (Pl. 2, Fig. 1)

Coloniae amphigenae, plerumque epiphyllae, tenues, ad $3 \mathrm{~mm}$ diam., confluentes et patentiae. Hyphae pallide brunneae, undulatae, oppositae vel irregulariter laxe ramosae, laxe reticulatae, cellulae 21-36 x 4-6 $\mu \mathrm{m}$. Appressoria alternata vel unilateralis, unicellularis, ovata, subglobosa, integra vel sublobata, lata posita, sessilis, 4-12 x 7-12 $\mu \mathrm{m}$. Thyriothecia laxe dispersa, orbicularis, saepe connata, ad $100 \mu \mathrm{m}$ diam., stellatim dehiscentes ad centro, crenatae vel fimbriatae ad 
margine, hyphae fringiorae flexuosae; asci pauci vel numerosi, globosi, octospori, ad $43 \mu \mathrm{m}$ diam.; ascosporae oblongae, conglobatae, brunnae, uniseptatae, constrictus ad septatae, $14-17$ x 8-10 $\mu \mathrm{m}$, parietus echinulatus.

Colonies amphigenous, mostly epiphyllous, thin, up to $3 \mathrm{~mm}$ in diameter, confluent and cover almost upper surface of the leaves. Hyphae pale brown, undulate, branching opposite to irregular at wide angles, loosely reticulate, cells 21-36 x 4-6 $\mu \mathrm{m}$. Appressoria alternate to unilateral, unicellular, ovate, subglobose, entire to sublobate, broad based, sessile, 4-12 x 7-12 $\mu \mathrm{m}$. Thyriothecia loosely scattered, orbicular, often connate, up to $100 \mu \mathrm{m}$ in diameter, stellately dehisced at the centre, crenate to fimbriate at the margin, fringed hyphae flexuous; asci few to many, globose, octosporous, up to $43 \mu \mathrm{m}$ in diameter; ascospores oblong, conglobate, brown, uniseptate, constricted at the septum, 14-17 x 8-10 $\mu \mathrm{m}$, wall echinulate.

\section{Materials examined: type}

On leaves of Aristolochia tagala Cham. (Aristolochiaceae); Cat. no. HCIO 48252; Loc. Peppara Wildlife Sanctuary, Thiruvananthapuram, Kerala; Coll. Jacob Thomas \& Vimalkumar; Date. 18-XI-2007. Isotype, Cat. no. TBGT 2991.

Asterina heterotropae Nakamura on Heterotropa hirsutisepala, from Japan and Asterina thotteae Hosagoudar \& Hanlin on Thottea spp. from India are reported on the family Aristolochiaceae (Katumoto, 1975; Hosagoudar \& Hanlin, 1995). However, the present species differs from both in having unicellular appressoria.

2. Asterina phyllanthi-beddomei sp. nov. (Pl. 2,Fig.2) Coloniae epiphyllae, subdensae, ad $1 \mathrm{~mm}$ diam., confluentes. Hyphae flexuosae vel anfractuae, alternata vel irregulariter laxe ramosae, laxe reticulatae, cellulae 28-43 x 3-5 $\mu \mathrm{m}$. Appressoria alternata vel unilateralis, bi-cellula, subantrorsa vel patentia, recta vel curvula, 9-15 $\mu \mathrm{m}$ longa; cellulae basilares cylindraceae vel cuneatae, 2-5 $\mu$ m longae; cellulae apicales ovatae vel plerumque globosae, 35- stellatim lobatae, 7-10 x 9-12 $\mu \mathrm{m}$. Thyriothecia dispersa, orbicularis, ad $140 \mu \mathrm{m}$ diam., stellatim dehiscentes ad centro, margine crenatae; asci numerosi, globosi, octospori, ad $38 \mu \mathrm{m}$ diam.; ascosporae oblongae, conglobatae, brunneae, uniseptatae, constrictus ad septae, 16-24 x 7-10 $\mu \mathrm{m}$, parietus glabrus.

Colonies epiphyllous, subdense, up to 1 $\mathrm{mm}$ in diameter, confluent. Hyphae flexuous to crooked, branching alternate to irregular at wide angles, loosely reticulate, cells 28-43 x 3-5 $\mu \mathrm{m}$. Appressoria alternate to unilateral, two celled, subantrorse to spreading, straight to curved, 9-15 $\mu \mathrm{m}$ long; stalk cells cylindrical to cuneate, $2-5 \mu \mathrm{m}$ long; head cells ovate to mostly globose, 3-5-times stellately lobate, 7-10 x 9-12 $\mu \mathrm{m}$. Thyriothecia scattered, orbicular, up to $140 \mu \mathrm{m}$ in diameter, stellately dehisced at the centre, margin crenate; asci many, globose, octosporous, up to $38 \mu \mathrm{m}$ in diam.; ascospores oblong, conglobate, brown, uniseptate, constricted at the septum, 16-24 x 7-10 $\mu \mathrm{m}$, wall smooth.

\section{Materials examined: type}

On leaves of Phyllanthus beddomei (Gamble) M. Mohanan (Euporbiaceae); Cat. no. HCIO 48869; Loc. Peppara Wildlife Sanctuary, Thiruvananthapuram, Kerala; Coll. Jacob Thomas; Date. 27-II-2008. Isotype, Cat. no. TBGT 3245.

Two species of the genus Asterina, namely, A. phyllanthicola Sudama Singh and A. phyllanthigena Hosagoudar are known on the host genus Phyllanthus (Hosagoudar, 2004; Singh, 1980). However, the present new species differs from both in having typically lobate head cells of the appressoria.

Key to the Asterina species known on the genus Phyllanthus

1. Appressoria lobate ...... Asterina phyllanthi-beddomei Appressoria entire ................................... 2

2. Form mycelial net .................... A. phyllanthigena Not so A. phyllanthicola

\section{Asterina thunbergiicola Hansford indica var. nov. (Pl. 3, Fig. 3)}

Differt a var. thunbergiicola appressoriis et ascosporis longioribus.

Colonies hypophyllous, thin, crustose, up to $5 \mathrm{~mm}$ in diameter, confluent. Hyphae crooked, branching irregular at various angles, loosely reticulate to form a mycelial net, cells 21-34 x 2-5 $\mu \mathrm{m}$. Appressoria alternate, two celled, straight to curved, plugged around stomata of the host leaf, 12-24 $\mu \mathrm{m}$ long, stalk cells cylindrical, 7-12 $\mu \mathrm{m}$ long; head cells ovate, globose to hamate, subangular, angular, narrowly to deeply lobate, 4-12 x 9-15 $\mu \mathrm{m}$. Thyriothecia scattered, orbicular, often 1-2 connate, up to $180 \mu \mathrm{m}$ in diameter, stellately dehisce at the centre and dissolved later, margin crenate; asci few to many, globose, octosporous, up to $30 \mu \mathrm{m}$ in diam.; ascospores, conglobate, brown, uniseptate, constricted at the septum, 16-22 x 7-10 $\mu \mathrm{m}$, wall smooth. Pycnothyria similar to thyriothecia, smaller; pycnothyriospores pyriform, brown, 
apiculate, broadly rounded at one end and, attenuated and truncate at the other, 16-22 x 9-15 $\mu \mathrm{m}$, wall smooth.

Materials examined: type

On leaves of Thunbergia sp. (Thunbergiaceae); Cat. no. HCIO 48870; Loc. Peppara Wildlife Sanctuary, Thiruvananthapuram, Kerala; Coll. Jacob Thomas; Date. 28-II-2008. Isotype, Cat. no. TBGT 3246.

Asterina thunbergiicola Hansford is known on Thunbergia chrysops from Sierra Leone, Uganda (Hansford, 1945). However, the new variety differs from the var. thunbergiicola in having longer appressoria and ascospores.

\section{Cirsosia hopeae sp. nov. (Pl. 3, Fig. 4)}

Coloniae epiphyllae, subdensae, ad $2 \mathrm{~mm}$ diam. Hyphae rectae, plerumque oppositae acuteque ramosae, laxe reticulatae, cellulae 38-48 x 9-12 $\mu \mathrm{m}$. Appressoria intercalaris, ovata, saepe leniter lateralis, 9-15 $\mu \mathrm{m}$ diam. Thyriothecia dispersa, ad initio rotundata vel ovata, elongata ad maturitata cum rima longitudinalis ad centre, 300-470 x 250$300 \mu \mathrm{m}$, margine crenatae vel fimbriatae, hyphae fringiorae rectae, arte aggregatae et parallel, nonappressoriatae; asci numerosi, globosi, octospori, 35-44 $\mu \mathrm{m}$ diam.; ascosporae obovatae, conglobatae, uniseptatae, fortiter constrictus ad septatae, cinnameo brunnneae, 22-25 x 11-13 $\mu \mathrm{m}$, parietus echinulatus. Pycnothyria numerosa, thyriotheciis similis; pycnothyriosporae unicellularis, fortiter brunnneae, pyriformes, leniter papillatae, 18-20 x 11-13 $\mu \mathrm{m}$.

Colonies epiphyllous, subdense, up to 2 $\mathrm{mm}$ in diameter. Hyphae straight, branching mostly opposite at acute angles, loosely reticulate, cells 3848 x 9-12 $\mu \mathrm{m}$. Appressoria intercalary, ovate, often slightly lateral, 9-15 $\mu \mathrm{m}$ in diam. Thyriothecia scattered, initially round to ovate, elongated at maturity with a longitudinal slit at the centre, 300$470 \times 250-300 \mu \mathrm{m}$, margin crenate to fimbriate, fringed hyphae straight, closely aggregated and parallel, devoid of intercalary appressoria; asci many, globose, octosporous, 35-44 $\mu \mathrm{m}$ in diam.; ascospores obovate, conglobate, uniseptate, deeply constricted at the septum, cinnamon brown, 22-25 x 11-13 $\mu \mathrm{m}$, wall echinulate. Pycnothyria many, similar to thyriothecia; pycnothyriospores unicellular, deep brown, pyriform, slightly papillate, $18-20$ x 11-13 $\mu \mathrm{m}$.

Materials examined: type

On the leaves of Hopea ponga (Dennst.) Mabb. (Dipterocarpaceae); Cat. no. HCIO 48846; Loc. near
Peppara Wildlife Sanctuary, Thiruvananthapuram, Kerala; Coll. Jacob Thomas and Vimalkumar; Date. 31III-2007. Isotype, Cat. no. TBGT 3222.

Intercalary appressoria, elliptical to elongated thyriothecia with longitudinal dehiscence are the characteristic of the genus Cirsosia. There are five species of the genus Cirsosia are known. Of these, C. arecacearum Hosagoudar \& Pillai, $C$. globuliferae (Pat.) Arx. and C. transversalis Bat. \& Maia are known on Arecaceae (Hosagoudar \& Pillai, 1993), while, C. irregularis (Sydow) Arx is known on Vatica obtusifolia from Philippines (Müller \& Arx, 1962). Cirsosia hopeae differs from it in having epiphyllous colonies in contrast to the hypophyllous, straight mycelium in contrast to crooked, smaller thyriothecia against 750 x 200-300 $\mu \mathrm{m}$ and smaller ascospores 23-25 x 11-12 against 35-36 x 15-16 $\mu \mathrm{m}$.

\section{Acknowledgements}

We thank Director (TBGRI) for the facilities. We are grateful to Ministry of Environment and Forest, New Delhi for the financial support and to the Forest Department, Govt. of Kerala for the forest permission.

\section{Literature cited}

Hansford, C. G., 1945. Contributions towards the fungus flora of Uganda VII. New records and revisions. Proceedings of Linnean Society London, 157: 20-41.

Hosagoudar, V. B. and C. M. Pillai, 1993. Two interesting Cirsosia species on Calamus from India. Mycological Research, 95: 127-128.

Hosagoudar, V. B., 2004. A new Asterina species from Kerala, India. Zoos' Print Journal, 19: 1522.

Hosagoudar, V. B. and R. T. Hanlin, 1995. New species of Asterina and Echidnodes from India. New Botanist, 22: 187-192.

Katumoto, K., 1975. The Hemisphaeriales in Japan. Bulletin of the faculty of agriculture, Yamaguti University, 26: 45-122.

Müller, E. and J. A. V. Arx, 1962. Die Gattungen der didymosporen Pyrenomyceten. Beitrage zur Kryptogamenflora der Schweiz, 11: 1-922.

Singh, S., 1980. Asterina phyllanthicola sp. nov. from India. Transactions of the British Mycological Society, 74: 204-205. 


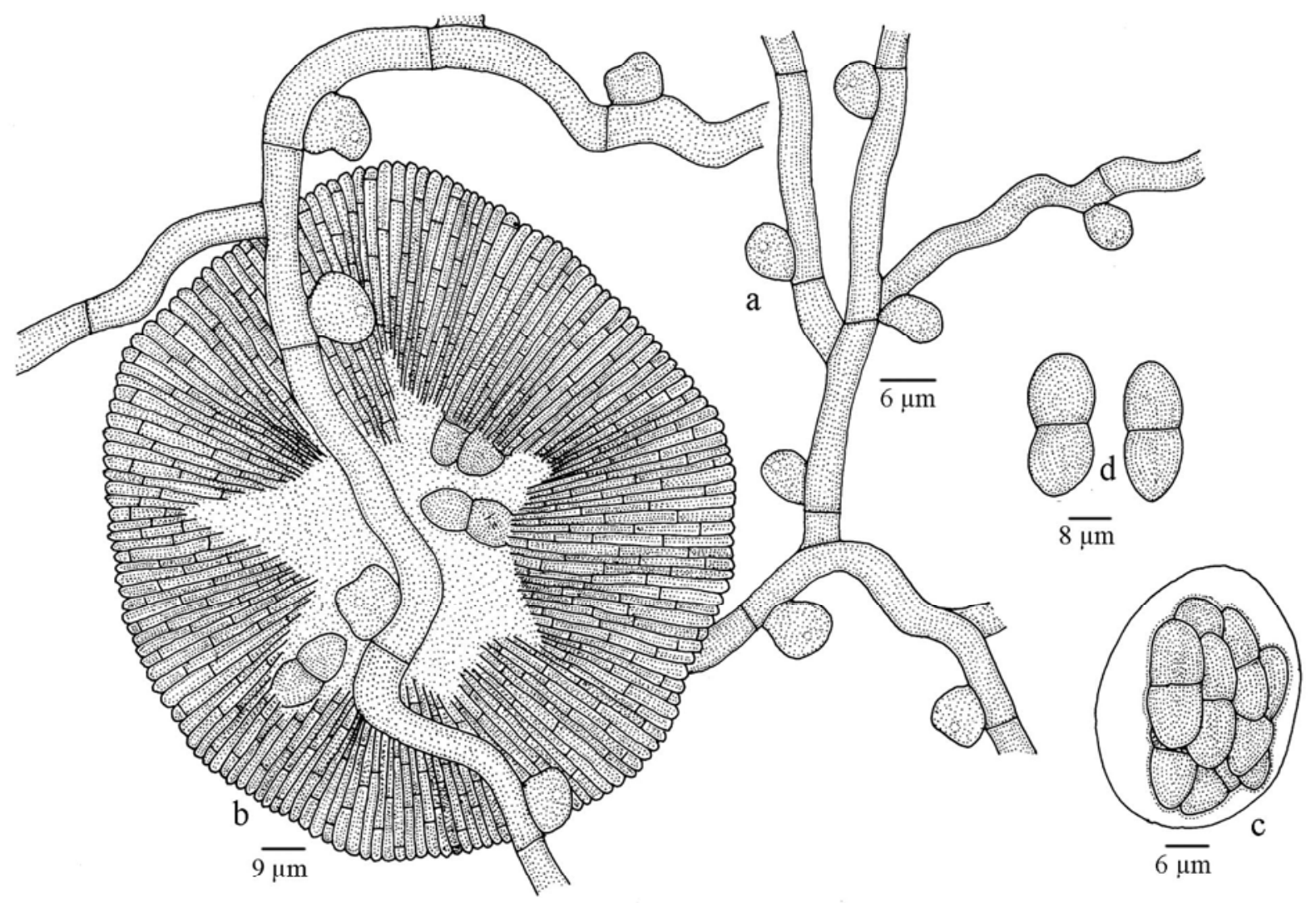

Fig. 01: Asterina aristolochiae Hosagoudar, Thomas \& Agarwal sp. nov.

a. Appressoriate mycelium, b. Thyriothecium, c. Ascus, d. Ascospores

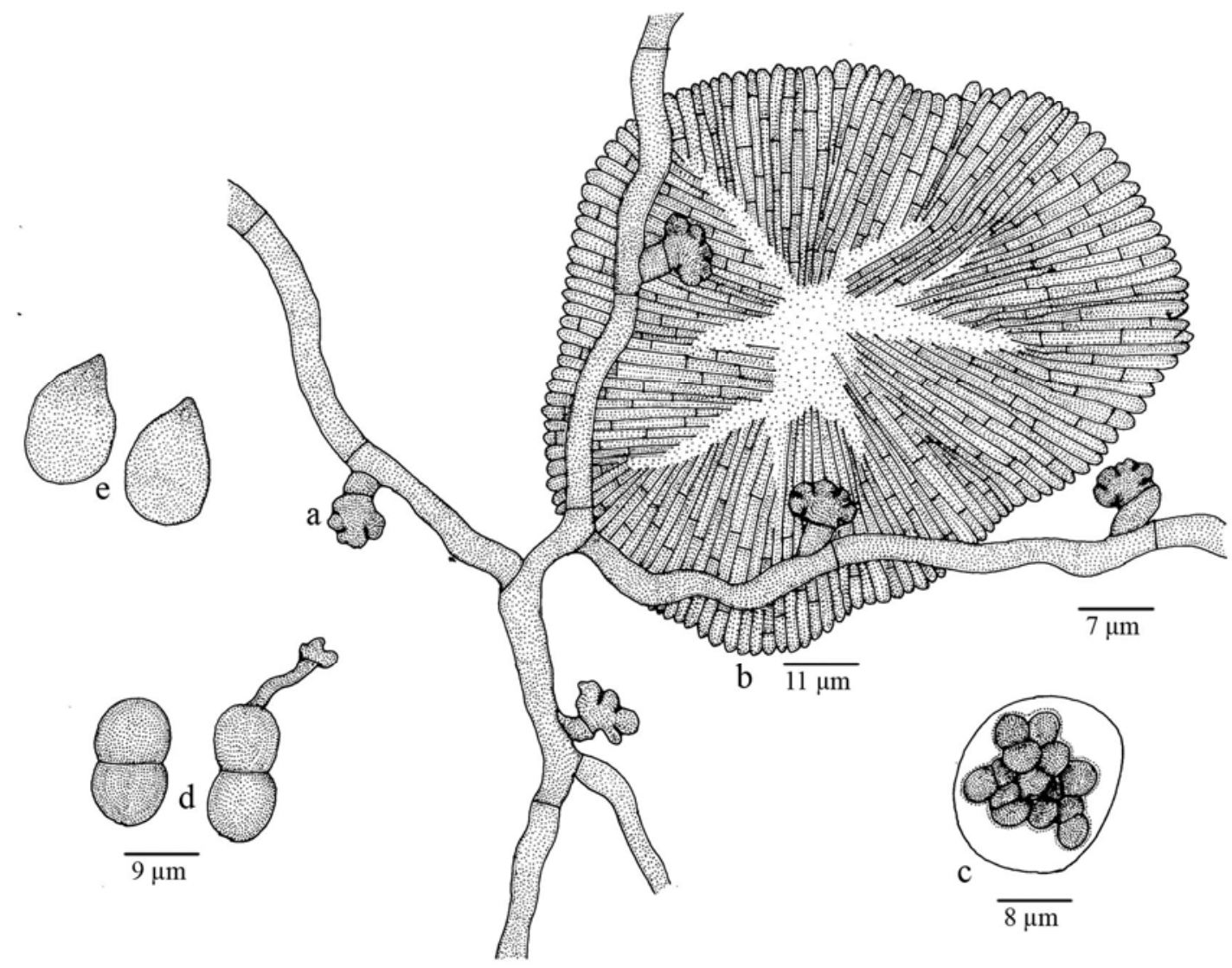

Fig. 02: Asterina phyllanthi-beddomei Hosagoudar, Thomas \& Agarwal sp. nov.

a. Appressoriate mycelium, b. Thyriothecium, c. Ascus, d. Ascospores, e. Pycnothyriospores 


\section{PLATE 03}
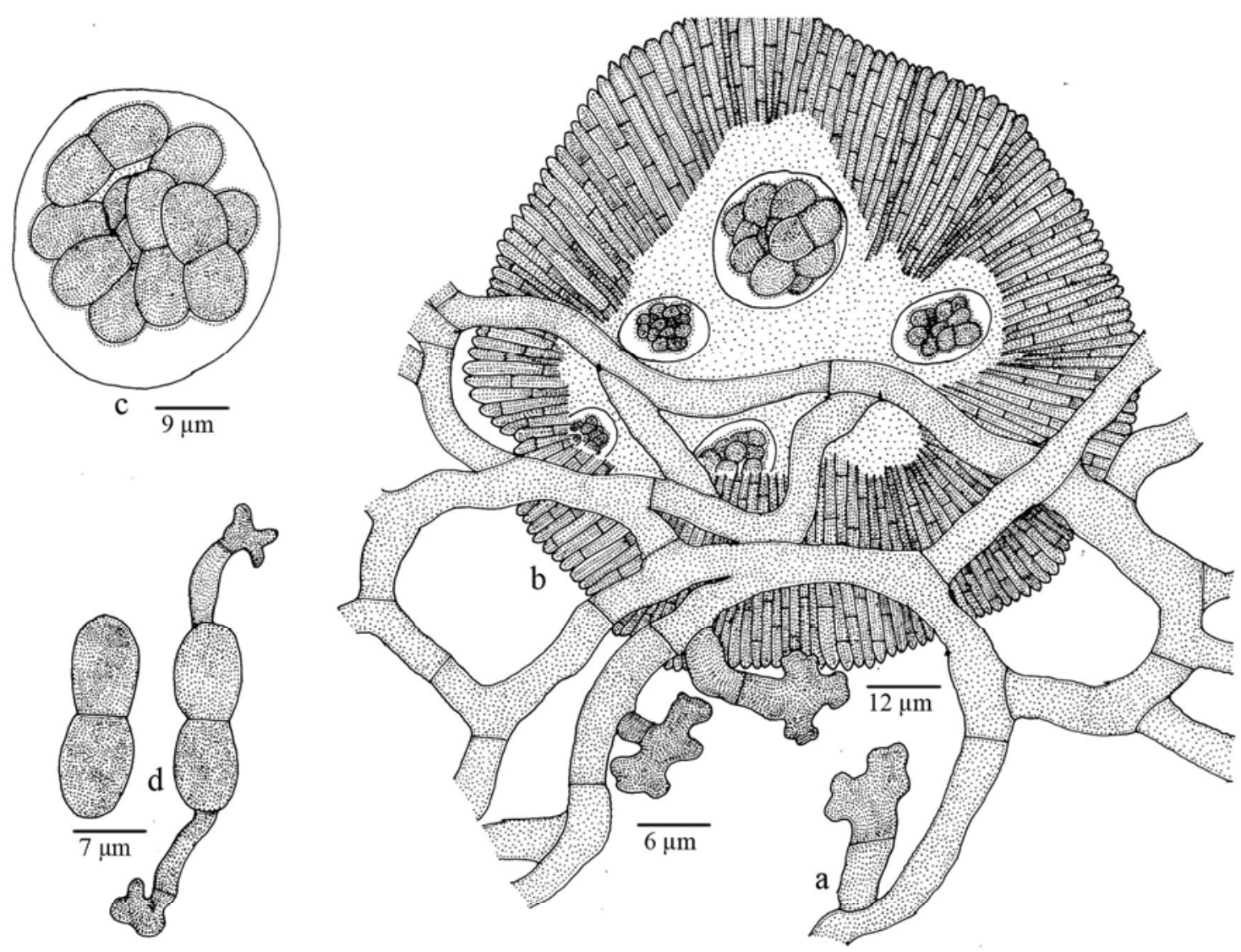

Fig. 03: Asterina thunbergiicola Hansf. var. indica Hosagoudar, Thomas \& Agarwal var. nov.

a. Appressoriate mycelium, b. Thyriothecium, c. Ascus, d. Ascospores

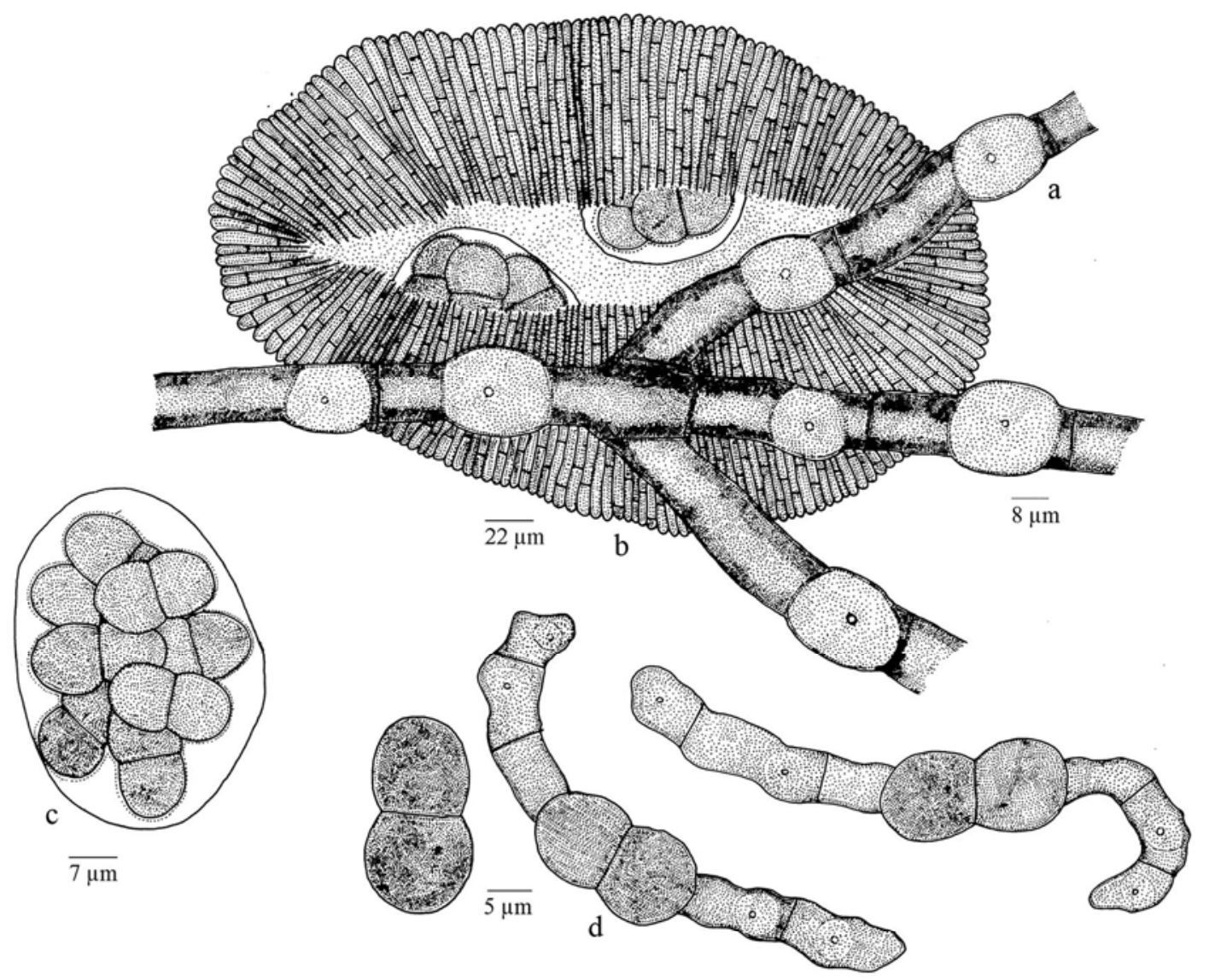

Fig. 04: Cirsosia hopeae Hosagoudar, Thomas \& Agarwal sp. nov.

a. Appressoriate (intercalary) mycelium, b. Thyriothecium, c. Ascus, d. Ascospores 